\title{
The Decline in the U.S. Personal Saving Rate: Is It Real and Is It a Puzzle?
}

\author{
Massimo Guidolin and Elizabeth A. La Jeunesse
}

\begin{abstract}
Since the mid-1990s, the national income and product accounts personal saving rate for the United States has been trending down, dropping into negative territory for three months during the past two years. This paper examines measurement problems surrounding two of the standard definitions of the personal saving rate. The authors conclude that, despite these measurement problems, the recent decline of the U.S. personal saving rate to low levels seems to be a real economic phenomenon and may be a cause for concern for several reasons. After examining several possible explanations for the trend advanced in the recent literature, the authors conclude that none of them provides a compelling explanation for the steep decline and negative levels of the U.S. personal saving rate. (JEL D10, E21)
\end{abstract}

Federal Reserve Bank of St. Louis Review, November/December 2007, 89(6), pp. 491-514.

T

he national income and product accounts (NIPA) personal saving rate computed by the Bureau of Economic Analysis (BEA) includes households and other nonprofit institutions and entities (such as charities and churches), and it is calculated simply by taking the difference between disposable personal income (essentially, incomes of all kinds minus taxes) and personal consumption expenditures (outlays including non-mortgage interest payments), then dividing this quantity (i.e., personal saving) by disposable personal income (see Figure 1). ${ }^{1}$

In the past two decades, the widely reported NIPA personal saving rate for the United States has been trending down, dropping from averages of around 9 percent in the 1980s, to approximately 5 percent in the 1990s, to almost zero in the first years of the new century. Recent reports in the media have alerted the public that the U.S. saving

1 In Figure 1, the dotted curve represents the NIPA personal saving rate reported by the BEA after the revision of July 31, 2007. rate, as currently measured, is at its lowest level since 1933, the bleakest year of the Great Depression. Of course, this historical comparison is disturbing at a minimum. Moreover, monthly data on household debt service payments as a percent of personal income have reached all time highs (see Poole, 2007).

The strongly declining trend in Figure 1 poses a number of problems. Taken at face value, a negative personal saving rate simply means that U.S. households are consuming more than their after-tax income allows them to. This tendency seems to be structural: For instance, the U.S. personal saving rate has remained persistently non-positive since April 2005. One naturally wonders whether it really can be true that the United States has become a spendthrift nation.

On a deeper level, many researchers and commentators have expressed a concern that the recent down-trending behavior of the U.S. personal saving rate may pave the way to a structural and persistent dependence of the U.S. economy on savings coming from foreign individuals and

Massimo Guidolin is an assistant vice president and Elizabeth A. La Jeunesse was a senior research associate at the Federal Reserve Bank of St. Louis. The authors thank Bill Gavin, Bill Poole, and Bob Rasche for comments and encouragement on previous drafts of this manuscript. 


\section{Figure 1}

\section{NIPA: Personal Saving as a Percent of Disposable Personal Income (monthly, SA)}

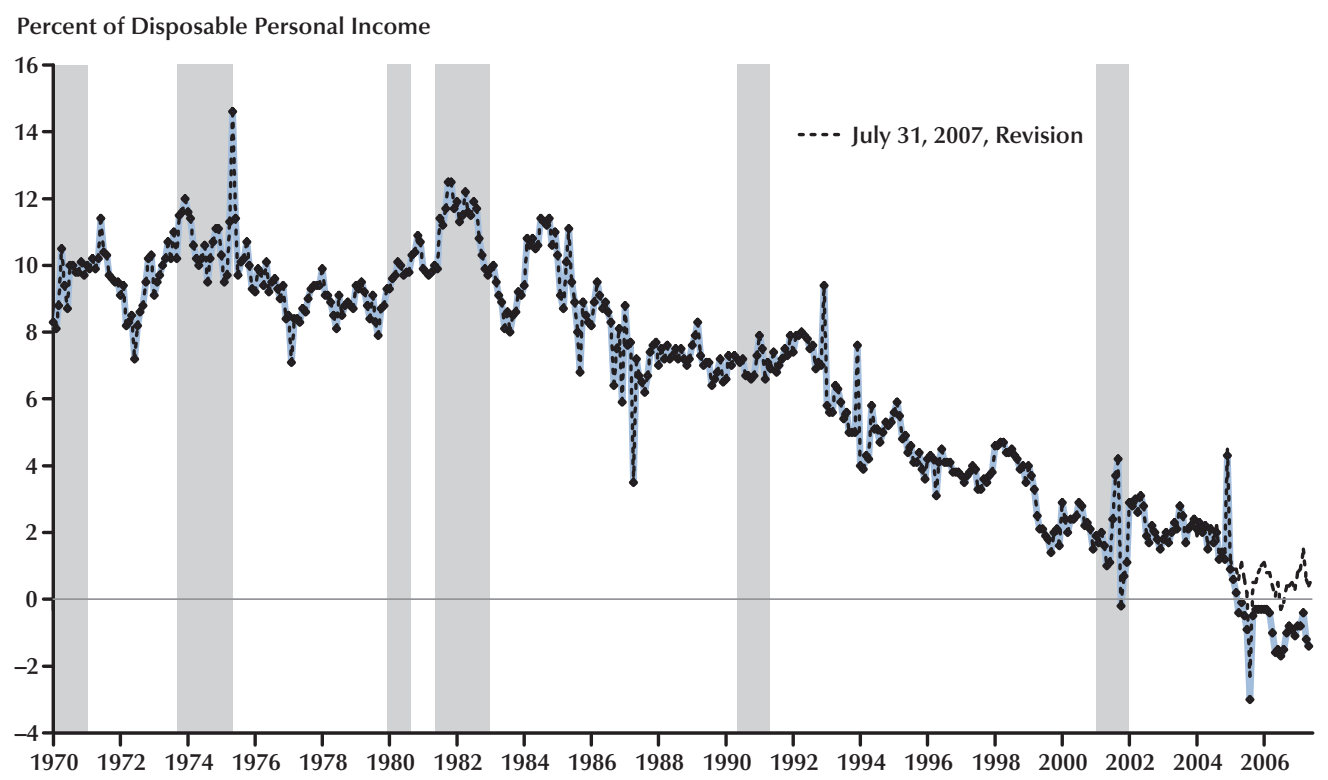

NOTE: Shaded bars indicate recessions.

SOURCE: Bureau of Economic Analysis.

firms, in the form of structural current account deficits. ${ }^{2}$ As argued by a number of authors (see Poole, 2005, for a review of the basic arguments), a situation in which the U.S. net international investment position keeps growing more negative

2 From Poole (2007): "Reports in the financial press have discussed the rapid accumulation of foreign exchange reserves by China, held mostly in U.S. dollars, and speculated on the impact on U.S. interest rates and the dollar exchange rate should the Chinese choose to diversify a significant fraction of such holdings out of dollars." According to economic theory, some uncertainty surrounds the relationship between running a large, persistently negative net international investment position and the future standard of living of the citizens of a country. In complete and frictionless markets, capital should simply flow toward the most productive uses, i.e. to projects with positive net present value and with the highest marginal return. Assuming that these projects systematically happen "to appear" within the U.S. borders, capital should keep flowing without any limits and this would raise the standard of living both in the United States and abroad. Of course, in reality, international capital markets are segmented and far from frictionless, and "states" (events) exist that-because large national economies are involved-are hardly insurable. All of these factors corroborate the contention that there are limits to the current account deficits that the United States may incur. For recent examples of papers that have discussed the notion of an optimal external debt ratio on the basis of frictions and market incompleteness, see, e.g.,

Fleming and Stein (2004) and Guimaraes (2007). as a percentage of gross domestic product (GDP) is inconsistent with long-run equilibrium: In such a situation, no debtor in the international financial market would be allowed to expand his position (as a percentage of output) without bounds. Because an adjustment is eventually inevitable, running a large current account deficit then becomes a risky strategy; hard landings-reductions of the international net debt position based on painful and disruptive adjustments in the domestic economy—may not be ruled out ex ante.

From simple macroeconomic principles, it is well known that the following accounting identity must hold at all times:

private gross investment $=$ personal saving + business saving + net saving of the public sector + borrowing from foreigners (current account deficit)

In other words, a given level of investments (mostly by firms) may be financed by household savings, by public sector surpluses (when it collects more taxes than current expenditures and 


\section{Figure 2}

\section{Private Saving Less Gross Investment as a Percent of GNP (quarterly, SA)}

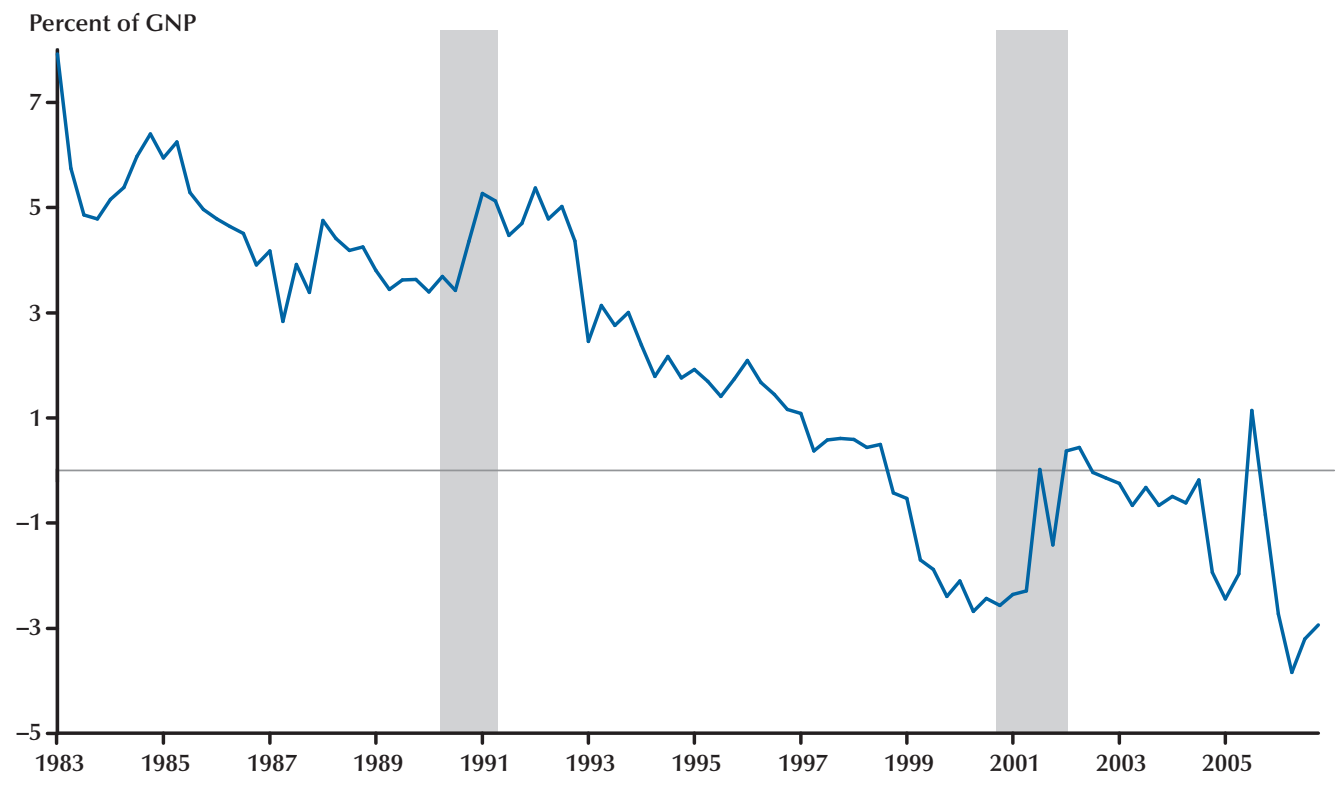

SOURCE: Bureau of Economic Analysis, Federal Reserve Board.

transfers), and by foreign investment. Of course, firms themselves may elect to retain some of their current earnings (profits) to finance future investments. Usually we assume that the public sector will not be able to set aside consistent savings, whereas according to simple logic, firms ought to be investing more resources than simply retained earnings. ${ }^{3}$ This leaves only two other possible sources of funds to finance gross investments: personal saving and borrowing from abroad. Consequently, because we have argued that it is sensible to think that a country would want to avoid large current account (external) deficits for protracted periods (to avoid building up massive international debt positions), ${ }^{4}$ it is usually con-

3 This does not mean that the saving of the public sector cannot be positive, although it usually tends to be limited. For instance, between 1980 and 2006 the average ratio between public sector savings (budget surpluses) and GNP has been -2.2 percent. Additionally, the recent debate on the future of the Medicare and Social Security programs implies that most experts predict large and growing federal budget deficits (negative savings of the public sector) for a few decades to come. sidered healthy (sustainable) that, at least in the long-run,

$$
\begin{gathered}
\text { private gross investment } \leq \text { (personal saving } \\
+ \text { business saving) } \equiv \text { private saving, }
\end{gathered}
$$

i.e., that total private saving should at least cover total gross investment, or

(1) private gross investment - business saving $\leq$ personal saving.

Given the presumption that the left-hand side will be positive most of the time, it is obvious that this inequality cannot be satisfied when personal saving turns negative for long periods of time. In fact, Figure 2 shows that, since 1999, private gross investment has systematically exceeded private saving. Moreover, at the end of 2005, the U.S. net international investment position was reported to be over -20 percent of out-

4 Using Gale and Sabelhaus's (1999, p. 182) wording, this "breeds increasing dependence on fickle foreign capital." 
put, another all-time low that has attracted some further concerns and a heated debate (see Poole, 2005).

As recently stressed by Garner (2006), the risk of an increased dependence from foreign savings is not the only reason for concern. Although the aging trend of the U.S. population is a long-range one, all recent projections tell us that the share of the population 65 and older is destined to rise at a much faster pace than in the past, as the postwar Baby Boom generation ages. This trend, together with increasing medical costs in real terms, is likely to produce increasing liabilities for Social Security and Medicare programs (see Hakkio and Wiseman, 2006). This means that exactly when the United States will most need portions of its population to rely on their own personal savings to relieve the pressure on the federally funded programs, a likely saving crisis may make resources for financing investments dramatically scarce. ${ }^{5}$

Finally, especially during 2005, the financial press has often called attention to the existence of retrenchment risk in consumer spending, which might suddenly lead the U.S. economy into a recession. The concern is that-should the current personal saving rate be too low to be consistent with sound long-run household plans—a sudden correction of consumption habits may translate into a substantial reduction in consumption expenditure and therefore aggregated demand. This may impose an undesirable uncertainty for the optimal course of monetary policy. ${ }^{6}$

In this article we ask three separate questions. In the first section we ask whether the decline in the U.S. personal saving rate is real or a simple statistical artifact due to measurement problems. In particular, we review and discuss pros and

\footnotetext{
5 Standard life-cycle consumption models imply a declining saving rate over an agent's lifetime; i.e., youngsters should display high saving rates used to cumulate savings that go to finance negative saving rates (dis-saving) after retirement. As a result, as the overall population ages, the aggregate saving rate is likely to decline.

${ }^{6}$ Garner (2006) reports some back-of-the-envelope calculations by which a simple 1-percentage-point increase in personal savings would cause an annualized, same-quarter decline of 2.8 percent in real output. A word of caution is in order: Empirical research has so far failed to provide clear results on the causal links between saving rate dynamics and economic recessions. See Steindel (2007) for empirical evidence on this tenuous link.
}

cons of two standard definitions of the personal saving rate. Because the decline manifests itself in all standard measures and cannot be easily explained by measurement issues, our conclusion is that yes, the decline of the U.S. personal saving rate seems to be a real phenomenon worthy of further attention. In the second section, we ask whether one should worry about the recent downward-trending U.S. saving rate. Our results are ambiguous. We find there are potentially legitimate reasons for concern: For instance, after the mid-1990s, the tendency of non-financial corporations to retain a growing fraction of their earnings has failed to fully compensate the decline in household savings. We also find reasons to suspend an immediate judgment: For instance, similar declines have been recorded in a number of other countries, such as Canada and Australia. In the third section we ask whether economic research has developed any solid understanding of the recent dynamics of the U.S. saving rate. After reviewing a number of arguments and theories that have been proposed, we conclude that the recent decline and negative values of the U.S. private saving rate remain a puzzle.

\section{IS THE DECLINE REAL? MEASUREMENT ISSUES}

There are two basic sources of calculated values for the personal saving rate: the NIPA estimates from the BEA and the estimates of the changes in personal net wealth that can be computed from the flow of funds (FoF) accounts maintained at the Board of Governors of the Federal Reserve System (BOG). Although both measures tend to receive some press coverage and are routinely cited in the economic debate, the NIPA estimates have recently enjoyed a great deal of attention in the financial press because-as shown in Figure 1-they turned negative during 2005. In what follows, we describe both measures, stressing their advantages and disadvantages. Generally, there are a number of reasons to think that both the NIPA and FoF measures provide an often-biased or, at best, incomplete representation of the saving behavior of U.S. households. 
One way to accurately define some of the criteria used and assumptions made by the BEA and the BOG when they compute the personal saving rate is to start from the basic budget constraint of a standard representative consumer:

$$
\begin{aligned}
& W_{t+1}= \\
& \left(1+r_{t+1}\right) W_{t}+L_{t+1}-C_{t+1}-\tau\left[r_{t+1} W_{t}+L_{t+1}\right]
\end{aligned}
$$

where $W_{t}$ is tradable net wealth (financial and real, e.g., including stocks, bonds, check deposits, and housing); $r_{t+1}$ is the overall (before tax) rate of return on wealth (e.g., capital gains, dividends, coupons, rents received from owned houses) over the interval; $L_{t}$ is labor income; $C_{t}$ is current consumption (personal outlays); and $\tau$ is the (average) tax rate, assumed to be constant for simplicity. $\tau r_{t+1} W_{t}$ corresponds, then, to the taxes paid on capital gains (notice, both realized and unrealized), while $\tau L_{t+1}$ are the taxes paid on labor income. ${ }^{7}$ Notice that $W_{t}$ is wealth net of debt and obligations (also called net worth). Equation (2) implies

(3) $W_{t+1}-W_{t}=r_{t+1}(1-\tau) W_{t}+(1-\tau) L_{t+1}-C_{t+1}$,

That is, changes in wealth must equal the difference between net disposable (after tax) income and consumption. Crucially, the left-hand side of (3) corresponds to a FoF definition of personal saving, while the right-hand side corresponds to a definition based on the difference between income and demand flows (disposable income and personal outlays). In an ideal, frictionless world with no measurement errors or problems with accounting definitions, the NIPA and FoF definitions would perfectly agree, just because the left- and right-hand sides of (3) coincide by construction. In the following, we discuss what in reality may cause the two definitions to differ, as well as the pros and cons of each definition.

\footnotetext{
7 This equation, which transforms differences of flows into stocks, is obviously a simplified description that abstracts from many important practical details. For instance, it is clear that capital gains may be taxed at a rate different from labor income; in reality, only realized capital gains (besides dividends, coupons, and rents) are taxed; households may receive and/or pay transfers to the public sector, etc. However, for the purpose of describing differences between NIPA and FoF definitions, this equation will do. Many of the simplifying assumptions will be removed later on.
}

The BEA defines the personal saving rate as the ratio of (i) the difference between disposable personal income and current consumption and (ii) disposable personal income (the right-hand side of (3)) divided by disposable personal income. Note that this focus on flows of personal income and outlays has the potential to create a number of accounting discrepancies: Disposable income and personal outlays are two series that are collected from distinct bodies of data. Income data are collected from payroll data, Internal Revenue Service income tax filings, and corporate profit reports. Personal outlays derive almost entirely from personal consumption expenditures, i.e., the data that come from the revenues of retailers and service suppliers (such as hospitals and hotels. The more complete and reliable data are those concerning the demand (consumption) side, whereas income data are notoriously imprecise, for instance, typically failing to add up to aggregate GNP by as much as 2 to 3 percent (the socalled statistical discrepancy). This means that income is usually underestimated, which suggests that NIPA saving rates may be subject to (i) substantial measurement error and (ii) frequent, major revisions as income data are progressively revised.

Besides these general limitations of the standard BEA and NIPA saving rate measures, a number of statistical and measurement issues have been debated in the literature on the U.S. saving rate evolution. The literature on the subject is rather voluminous. We choose to focus on at least four distinct aspects that may cause the measured NIPA personal saving rate to substantially differ from the true, unobserved personal saving rate. ${ }^{8}$

\section{NIPA Measures of the Personal Saving Rate and (Realized) Capital Gains}

Distortions are likely to be caused because NIPA conventions exclude (realized and unrealized) capital gains from disposable income but include taxes on the realized capital gains in the same definition of disposable income. Using the notations in (3), this means that the BEA measures

8 See, for instance, Garner (2006), Peach and Steindel (2000), and Reinsdorf (2004). 
disposable income as $(1-\tau) L_{t+1}-\rho_{t+1} \tau W_{t}$ and not as $(1-\tau) L_{t+1}-r_{t+1}(1-\tau) W_{t}$, where $\rho_{t+1} \neq r_{t+1}$ is the realized rate of return on wealth (i.e., inclusive only of realized, actual capital gains that have been transformed into cash). The difference is given by the term

$$
r_{t+1} W_{t}+\left(\rho_{t+1}-r_{t+1}\right) \tau W_{t},
$$

which may be sometimes substantial and-even when $\rho_{t+1}=r_{t+1}$, that is, all capital gains are realized-never disappears as long as $r_{t+1} \neq 0$. Formally, this means that while the NIPA personal saving rate is measured to be

$$
s_{t+1}^{N I P A}=\frac{(1-\tau) L_{t+1}-\rho_{t+1} \tau W_{t}-C_{t+1}}{(1-\tau) L_{t+1}-\rho_{t+1} \tau W_{t}},
$$

the true (but unobserved) rate should be

$$
\hat{s}_{t+1}=\frac{(1-\tau) L_{t+1}-r_{t+1}(1-\tau) W_{t}-C_{t}}{(1-\tau) L_{t+1}-r_{t+1}(1-\tau) W_{t}} .
$$

A few straightforward manipulations show that the unobservable personal saving rate can be written as

(5)

$$
\begin{aligned}
& \hat{s}_{t+1}= \\
& \underbrace{\frac{(1-\tau) L_{t+1}-\rho_{t+1} \tau W_{t}}{(1-\tau) L_{t+1}+r_{t+1}(1-\tau) W_{t}}}_{\kappa_{t+1}^{0}}(s_{t+1}^{N P A}+\underbrace{\frac{r_{t+1} W_{t}+\left(\rho_{t+1}-r_{t+1}\right) \tau W_{t}}{(1-\tau) L_{t+1}-\rho_{t+1} \tau W_{t}}}_{\kappa_{t+1}^{1}}), \\
& \hat{s}_{t+1} \simeq s_{t+1}^{N P A}+\kappa_{t+1}^{1} .
\end{aligned}
$$

For reasonable values of the quantities involvedessentially, when labor income represents a nonnegligible fraction of total initial net worth for households and for plausible tax rates because the coefficient $\kappa_{t+1}^{0}<1$ will be relatively close to 1 , but less than 1 , while $\kappa_{t+1}^{1}$ will be positive$\hat{s}_{t+1}>s_{t+1}^{N I P A}$ follows. ${ }^{9}$ This means that, provided

9 This happens because $r_{t+1}$ will normally exceed $\left(\rho_{t+1}-r_{t+1}\right) \tau$. For instance, for plausible values such as $\tau=0.25, r_{t+1}=0.1, \rho_{t+1}=0.05$, and $\kappa_{t+1}^{1}>0$ reduces to

$$
\frac{0.1 W_{t}+0.0125 W_{t}}{0.75 L_{t+1}-0.0125 W_{t}}=\frac{0.1125}{0.75 \frac{L_{t+1}}{W_{t}}-0.0125}>0 \Rightarrow \frac{L_{t+1}}{W_{t}}>0.017 .
$$

that the average tax rate and (realized and total) rates of return on assets are not too large, the NIPA personal saving rate is bound to systematically underestimate the true personal saving rate. Approximating (5) for the simple case in which $\rho_{t+1}=r_{t+1}$ and $\rho_{t+1} \tau \simeq 0$, we obtain

$$
\hat{s}_{t+1}-s_{t+1}^{N I P A} \simeq \frac{r_{t+1} W_{t}}{(1-\tau) L_{t+1}},
$$

which shows that the difference between the "true" saving rate and the NIPA estimate is proportional to the total capital gains of the economy. Figure 3 provides a description of the behavior of this quantity over time (as a percentage of disposable personal income) and illustrates the potential for substantial underestimation of the saving rate using NIPA accounts.

A few economists have taken issue with this broad definition of a "true" saving rate, $\hat{s}_{t+1}$, arguing that only realized capital gains should be considered. Three motivations are offered. Unrealized capital gains should not be included in the definition of saving as they simply represent returns on past saving activity, which has already been accounted for. In many cases, simple appreciation of existing assets (e.g., houses) fails to create new productive assets. The fact that unrealized gains fail (by definition) to be transformed into cash resources that allow households (or other agents that borrow from households) to acquire physical, productive capital stock should (consistent with current BEA practices) dissuade analysts from using capital gains altogether. Furthermore, it has been observed that a large portion of unrealized capital gains tends to arise in the presence of volatile "bubbling" conditions (e.g., the stock market boom of the late 1990s and possibly the housing price surge of 2002-05); as such, these gains have to remain unrealized almost by definition-if households tried to cash them in, they would cause the bubble to burst, causing the capital gains to vanish. ${ }^{10}$ Therefore it is debatable whether such unstable components should be

\footnotetext{
${ }^{10}$ Notice, however, that-assuming efficient credit markets with modest transaction costs-capital gains do not need to have been realized to cause an increase in personal outlays: Unrealized capital gains may be used as collateral to support additional borrowing.
} 


\section{Figure 3}

\section{Total Capital Gains (Losses) as a Percent of Disposable Personal Income (eight-quarter moving average)}

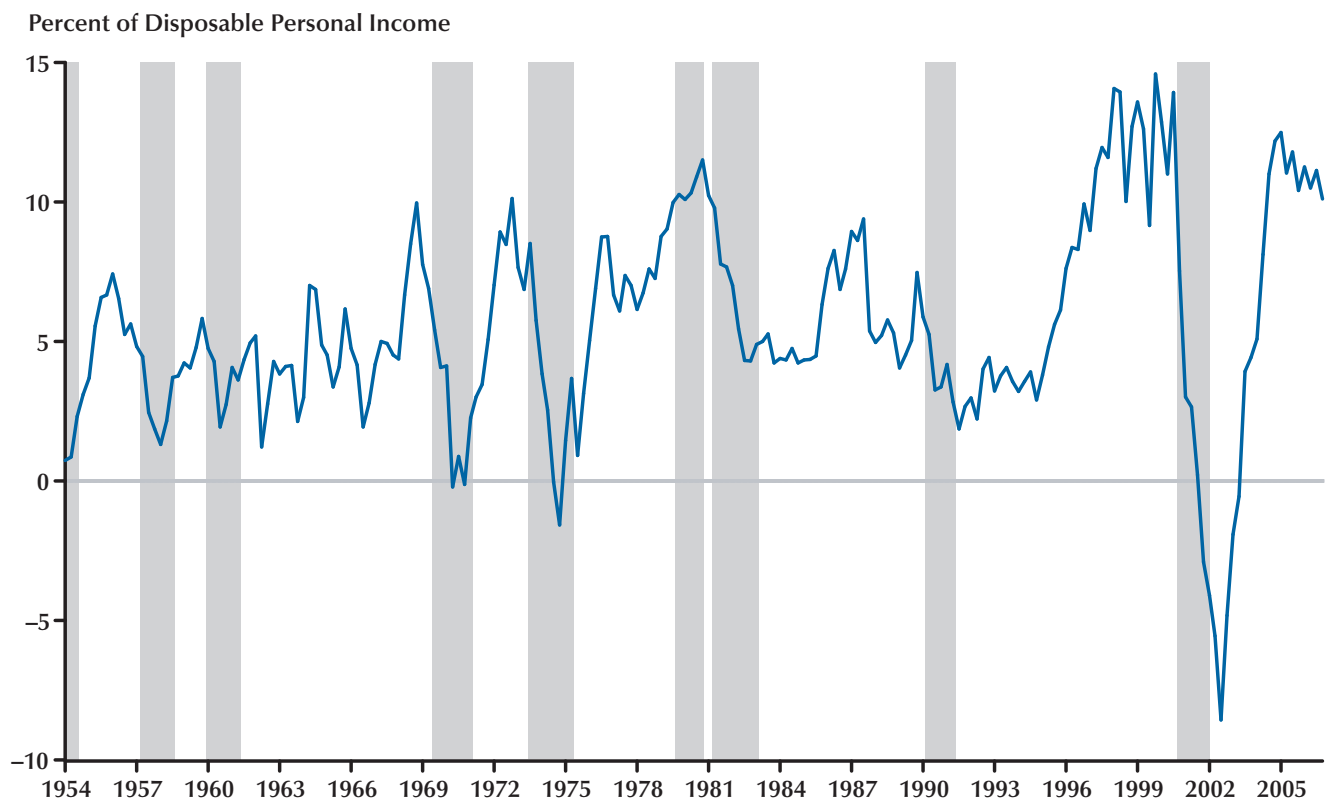

SOURCE: Federal Reserve Board.

considered as part of private saving. Third, in the empirical literature, considerable debate persists as to what fraction of such unrealized capital gains might be actually increasing saving the complement of the so-called "wealth effect" on consumption). ${ }^{11}$ When only realized capital gains are considered, the true (but unobserved) personal saving rate is defined as

$$
\tilde{s}_{t+1}=\frac{(1-\tau) L_{t+1}+\rho_{t+1}(1-\tau) W_{t}-C_{t}}{(1-\tau) L_{t+1}+\rho_{t+1}(1-\tau) W_{t}},
$$

\footnotetext{
${ }^{11}$ In the empirical literature, estimates are rather heterogeneous. Among many others, Poterba (2000) reports a tiny 3 percent elasticity of consumption to wealth, while Parker (2000) finds 4 percent. Ludvigson and Steindel (1999) report that the elasticity is small and the effect quickly dies out after one quarter. Such low estimates of the elasticity of consumption to wealth imply that most of the unrealized capital gains might be converted into savings. On the other hand, Juster et al. (2006) found a massive 19 percent elasticity for stock price increases, although the overall effect of wealth increases is consistent with the standard 3 percent in the literature. Therefore the impact of capital gains on saving might be much higher for housing (and other assets) than it is for equities.
}

with the implication that

(6)

$$
\begin{aligned}
& \tilde{s}_{t+1}= \\
& \underbrace{\frac{(1-\tau) L_{t+1}-\rho_{t+1} \tau W_{t}}{(1-\tau) L_{t+1}+\rho_{t+1}(1-\tau) W_{t}}}_{\kappa_{t+1}^{0}}\left(s_{t+1}^{N I P A}+\frac{\rho_{t+1} W_{t}}{(1-\tau) L_{t+1}-\rho_{t+1} \tau W_{t}}\right) .
\end{aligned}
$$

For reasonable values of the quantities involved, one can show that $\tilde{s}_{t+1}>s_{t+1}^{N I P A}$. Once more, the NIPA personal saving rate will systematically underestimate the true personal saving rate. As a first approximation, the amount of the bias is increasing in (proportional to) both the amount of realized capital gains, $\rho_{t+1} W_{t}$, and in the amount of taxes paid on the realized capital gains. ${ }^{12}$ Figures 4 and 5 show that the recent decline in the measured NIPA saving rate occurred simulta-

\footnotetext{
${ }^{12}$ Formal differentiation shows that the derivatives versus the tax rate and the realized capital gain rate of the term that is added to $s_{t}^{N I P A}$ inside the parenthesis are both positive.
} 


\section{Figure 4}

\section{NIPA Personal Saving and Total Realized Capital Gains (annual)}

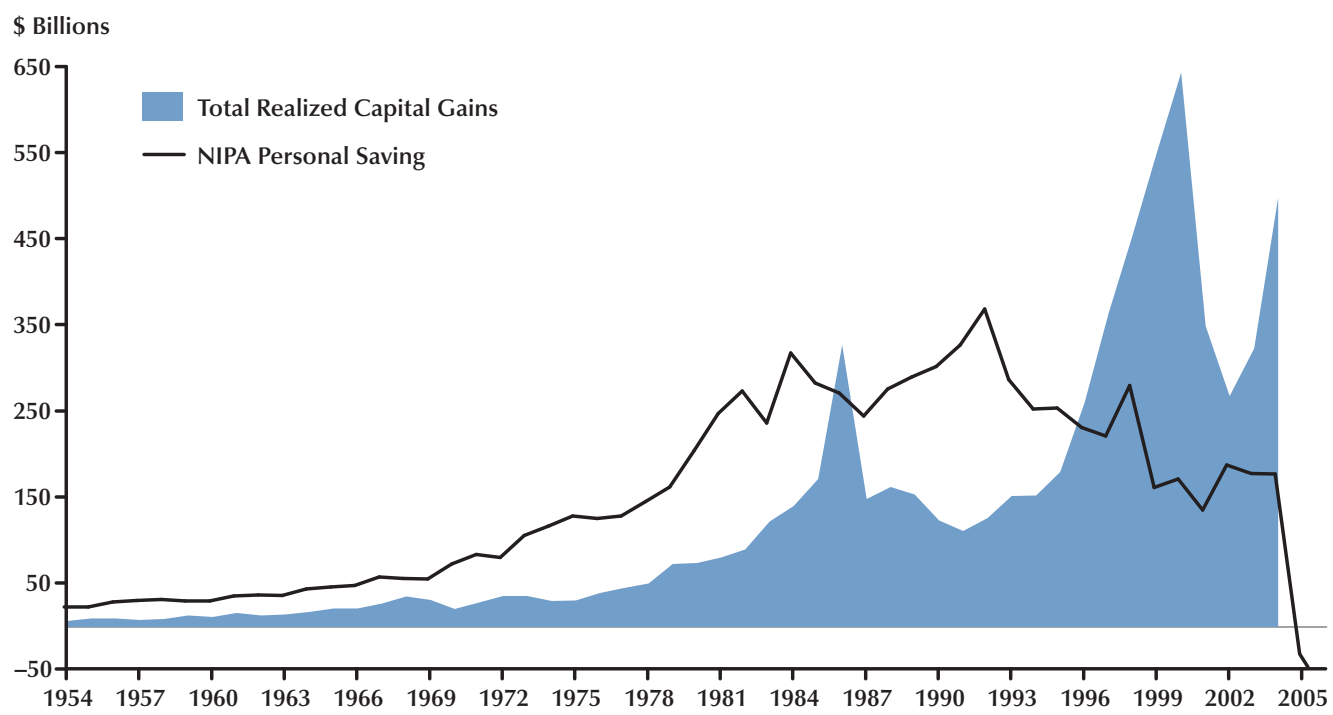

SOURCE: Bureau of Economic Analysis, U.S. Treasury.

\section{Figure 5}

\section{Capital Gains Tax Receipts Excluded from NIPA Disposable Personal Income (annual)}




neously with high realized capital gains and high capital gains taxes. Therefore a possibility exists that a substantial portion of the recent decline may be simply imputed to increasing biases (underestimation) in NIPA measures. Moreover, the capital gains issue is likely to become increasingly important not just because stock market gains have been substantial in recent years, but also because companies are using more and more share repurchases (and not cash dividends) to distribute profits to the shareholders. Share repurchases tend to increase stock prices, yielding capital gains to shareholders that do not appear in personal income. If companies increasingly use share repurchases instead of dividendswhich seems to characterize recent data-the result would be to create a growing downward bias in the measured NIPA saving rate.

Notice, however, that the most recent dramatic dip in the measured NIPA saving rate (during 2005) corresponds to a decline in the taxes paid on realized capital gains and-absent any major fiscal reform-in the realized capital gains themselves. In summary, although the NIPA measure of the personal saving rate is likely to underestimate the true, unobservable rate by a few percentage points, and some logical inconsistencies exist in the NIPA treatment of capital gains, it is difficult to conclude that these discrepancies entirely explain the declining trend in the NIPA measure or-especially - the negative saving rates that have been reported during 2005.

\section{NIPA Measures of the Personal Saving Rate and Pension Schemes}

A second, obvious flaw of NIPA measures of the personal saving rate is that the methodological criteria of the BEA exclude pension benefits received as disposable income, but deduct from personal disposable income the contributions paid into pension funds. Call the net pension benefits $n p b_{t+1}$, defined as the difference between gross benefits (transfers) received $\left(p b_{t+1}\right)$ and contributions $\left(p c_{t+1}\right), n p b_{t+1} \equiv p b_{t+1}-p c_{t+1}$. Then calculations similar to those performed above show that, although the NIPA personal saving rate is calculated as

$$
s_{t+1}^{N I P A}=\frac{(1-\tau) L_{t+1}-\rho_{t+1} \tau W_{t}-p c_{t}-C_{t+1}}{(1-\tau) L_{t+1}-\rho_{t+1} \tau W_{t}-p c_{t}}
$$

the true but unobserved personal saving rate is

$$
\begin{aligned}
& \tilde{s}_{t+1}= \\
& \frac{(1-\tau) L_{t+1}-\rho_{t+1} \tau W_{t}-p c_{t}}{(1-\tau) L_{t+1}+\rho_{t+1}(1-\tau) W_{t}+n p b_{t+1}-C_{t}} \\
& \left(s_{t+1}^{N I P A}+\frac{\rho_{t+1} W_{t}+p b_{t+1}}{(1-\tau) L_{t+1}-\rho_{t+1} \tau W_{t}-p c_{t}}\right) .
\end{aligned}
$$

Once more, if the ratio that precedes the sum in parenthesis is approximately 1 , then, because $\tilde{s}_{t+1}>s_{t+1}^{N I P A}$, the NIPA rate will systematically underestimate the actual saving rate. Figure 6 shows that the amount of net pension benefits received by U.S. households has substantially increased (as a percentage of the NIPA personal disposable income) since the mid-1990s, peaking at roughly 4 percent in 2001. As a result, it is likely that a portion of the downward-trending NIPA estimate of $s_{t+1}$ may be due to omitting pension benefits, although the quantitative relevance of the bias is probably of second-order importance. For instance, a quantitative estimate of the term $p b_{t+1} /(1-\tau) L_{t+1}$ as of the end of 2005 was approximately 14 percent. ${ }^{13}$

Another, different issue concerns the way in which the BEA treats defined benefits (DB) pension plans when computing the personal saving rate. NIPA estimates treat defined contribution (DC) plans in a perfectly consistent way: Because the employee directly owns the assets and retains a substantial amount of control, it seems correct for NIPA to include employers' contributions and capital gains and income as personal income and to consider the plan's administrative expenses as personal outlays. With DB plans, however, employers make the investment decisions and bear the investment risks. Moreover, DB plans can be a source of cash flows only upon retire-

\footnotetext{
${ }^{13}$ Notice that NIPA's treatment of IRAs and 401(k) plan contributions, for example, is perfectly consistent: Because these defined contributions are not part of personal outlays (and, therefore, must be included in the difference between personal income and personal outlays), they are correctly included in national saving computations.
} 


\section{Figure 6}

\section{Net Pension Benefits (annual)}

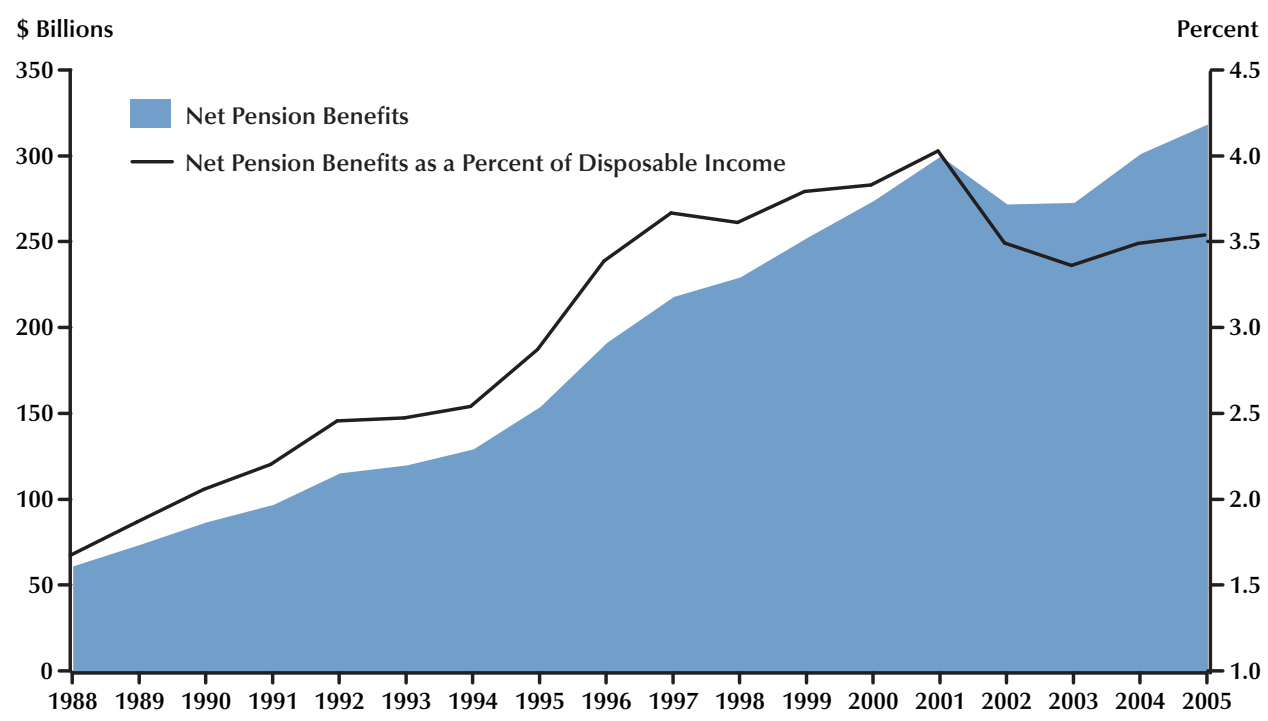

SOURCE: Bureau of Economic Analysis, U.S. Treasury.

ment and potential plan surpluses generally fail to be passed on to the employees to increase their pension benefits. These latter two features would suggest that DB plans should be considered in NIPA estimates of the personal saving rate, yet they are. In principle, if one thinks that in recent years DB plans have generated large net losses to households (i.e., that the employers' contributions have been modest relative to capital losses and administrative expenses), excluding DB pension plans from NIPA calculations may increase the measured personal saving rate over the actual (unknown) rate. A further issue is that, although investment income on DC plans is treated as personal income, payments out of both DC and DB plans are not. However, such payments are subject to income taxes and these taxes reduce measured personal disposable income-and hence the saving rate- at the time the retirement benefits are paid.

We therefore compute a modified NIPA saving rate that excludes DB pension plan-implied income and outlay components. First, we remove from personal income the employer contributions to DB plans as well as rental income, dividends, and interest; second, we add to personal income the benefits paid by DB plans net of employee contributions; and third, we remove from personal consumption expenditures the administrative expenses of DB pension. Figure 7 shows the results. There are two obvious implications. First, excluding DB plans generates quantitative implications of second-order importance. Second (and more important), when DB incomes and outlays are excluded, the implied personal saving rate is actually even lower than the official rate reported by the BEA. ${ }^{14}$

\section{Other Issues with the NIPA Measures of the Personal Saving Rate}

Economists and the financial press have focused on a few other accounting issues in their attempt to make sense of the recent decline (to negative territory) of the U.S. personal saving rate. First, the BEA's choice to consider net acquisitions

\footnotetext{
${ }^{14}$ Reinsdorf (2007, p. 9) reaches similar conclusions with data up to 2005 .
} 


\section{Figure 7}

\section{Alternative Personal Saving Rate with Defined Benefit Pensions Excluded (annual)}

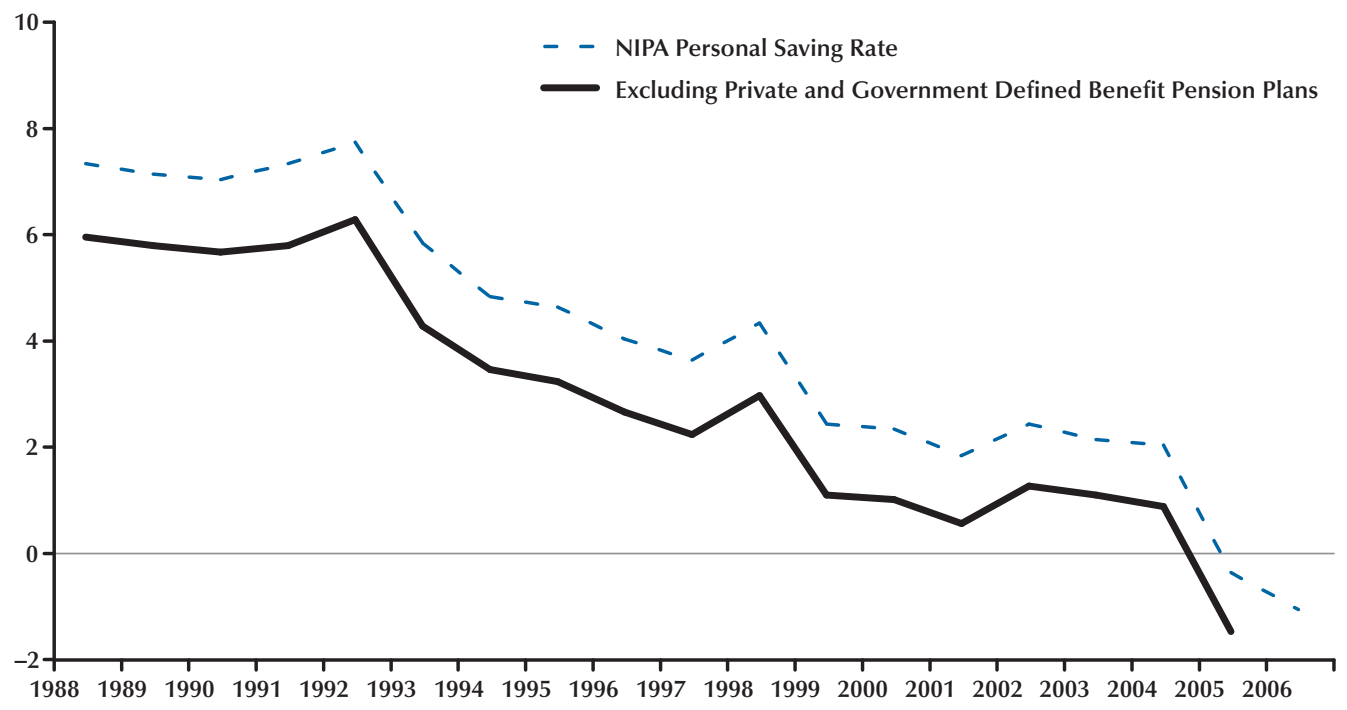

SOURCE: Bureau of Economic Analysis, Federal Reserve Board, author's calculations.

of consumer durable goods by households as personal consumption expenditures has been a cause of dissatisfaction: At least a portion of household purchases of durable goods (e.g., cars) have many features of an investment decision and increase the stock of physical capital that produces services over time. Of course, if we define the true personal saving rate as (notice that this ignores many issues already discussed)

$$
\breve{s}_{t+1}=\frac{(1-\tau) L_{t+1}-\rho_{t+1} \tau W_{t}-\left(C_{t+1}-C_{t+1}^{D U R}\right)}{(1-\tau) L_{t+1}-\rho_{t+1} \tau W_{t}},
$$

where $C_{t+1}^{D U R}$ is durable consumption, it is clear that

$$
\breve{s}_{t+1}=s_{t+1}^{N I P A}+\frac{C_{t+1}^{D U R}}{(1-\tau) L_{t+1}-\rho_{t+1} \tau W_{t}},
$$

which implies $s_{t+1}^{N I P A}>\breve{s}_{t+1}$. The amount by which the true saving rate is underestimated depends on the ratio between consumption of durables and personal disposable income. Figure 8 shows the behavior of such a ratio over time.

On the one hand, Figure 8 stresses that the ratio

$$
C_{t+1}^{D U R} /\left[(1-\tau) L_{t+1}-\rho_{t+1} \tau W_{t}\right]
$$

is quantitatively important. In fact, if computing the personal saving rate on the basis of durables only were the correct choice, then the reported personal saving rate could be at least 10 percent higher. On the other hand, Figure 8 reveals that the ratio between durables and personal disposable income has not changed much over timeit has constantly oscillated between 9.5 and 13 percent-and as such it cannot be responsible for the recent downward trend in the measured personal saving rate (see also Parker, 2000, for similar conclusions). With multiple possibilities, it's unclear what the "victory" would be. Notice, too, that if this treatment of durable consumption goods has the ability to shift up measured saving behavior of U.S. households by approximately 10 percent, then personal expenditures on durables should then be considered as a form of private, gross investment. If, however, as noted earlier, we believe that there is evidence that private gross saving might be currently insufficient in the United States, moving some items from con- 
Figure 8

\section{Ratio of Personal Consumption Expenditure of Durable Goods to Disposable Personal Income (quarterly, SAAR)}

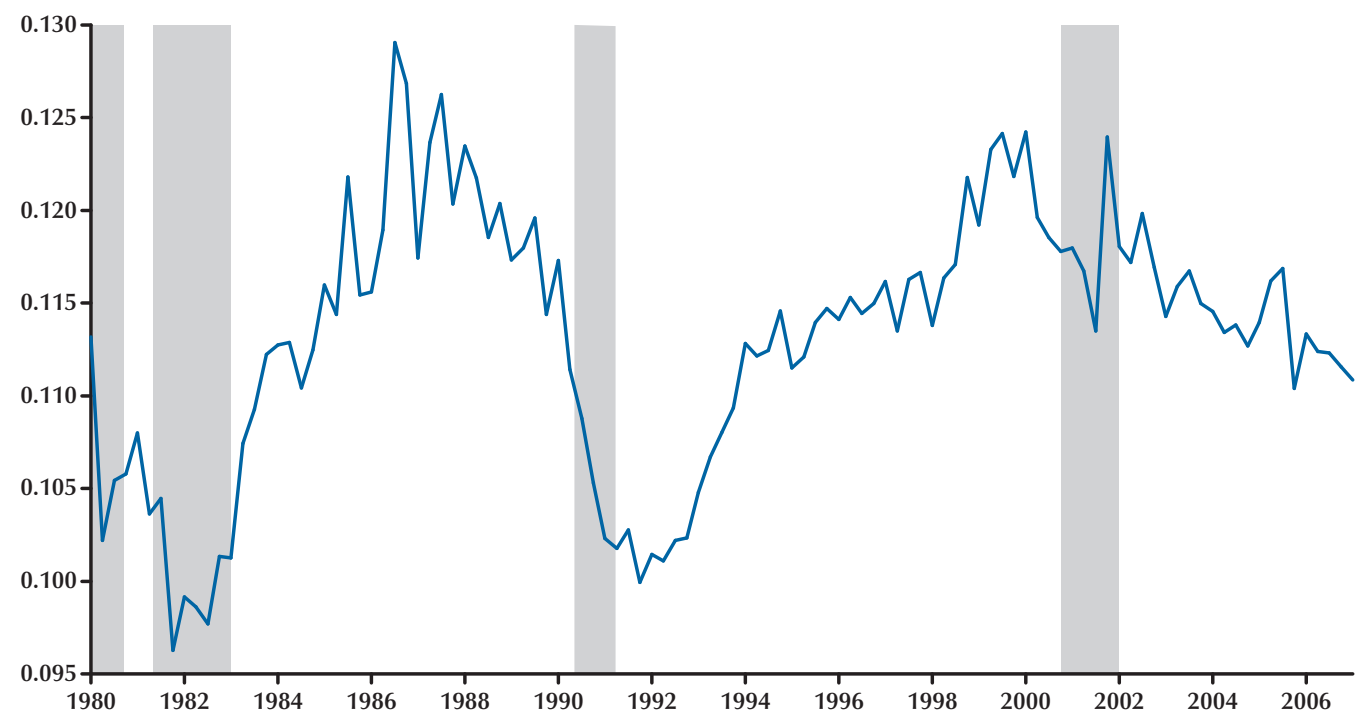

SOURCE: Bureau of Economic Analysis.

sumption to investments cannot solve the problem because the intervention raises both the leftand right-hand sides of the basic accounting identity in (1).

Commentators have also taken issue with the way in which the BEA defines the notion of "personal" sector. In principle, such a sector ought to include households and nonprofit institutions serving households (e.g., churches and charities, also called NPISH). NIPA methodological guidelines, however, do not consistently use this definition. For instance, bequests or gifts to charities are considered as personal outlays (and therefore reduce the reported saving rate) in standard NIPA accounts, although they should not be. The opposite happens when households receive transfers from NPISH. Obviously, as long as transfers by households to and from NPISH approximately balance out, no relevant bias will affect the reported saving rate. In fact, for a long time this has been approximately the case. Even though recent years have seen households increasing their transfers to NPISHs, Reinsdorf (2007) shows that the effect on the personal saving rate is marginal (0.6 percent between 1997 and 2002 and 0.2 after 2007).

Finally, other measurement issues that have been discussed (see, e.g., Reinsdorf, 2004, for additional details) are the use of nominal versus real interest rates in NIPA calculations of net interest payments by households, the treatment of real estate "closing" costs, and the nature of education expenditures. Perozek and Reinsdorf (2002) recalculate personal disposable income by replacing nominal personal interest income with real interest income (i.e., excluding the inflation premium, which purely compensates for the loss in value of existing assets). The idea is that saving should allow financing of capital accumulation in real terms and not simply serve as protection from inflation. However, this adjustment implies an overall downward adjustment of the personal saving rate (e.g., between 0.5 and 1.2 percent between 1993 and 2000) and fails to explain the recent, puzzling trend. It is also uncertain whether real estate closing costs (to purchase 
or mortgage a residence) should be considered as current personal outlays or as investments. Reinsdorf (2004) concludes that the impact is quantitatively marginal. Education expenditures by households are treated by NIPA as current consumption expenditures, even though they obviously increase the stock of human capital. Their exclusion from personal outlays would increase measured personal saving but also increase gross private investments, which also does not seem to solve the puzzle under investigation.

Recently, NIPA revised its policies concerning the way in which stock options are treated. Currently, stock options are treated in a manner consistent with IRS practices: When exercised, options generate wage incomes to recipients and expenses to corporations; however, holdings of stock options fail to generate (non-realized) capital gains before the option is exercised. This clearly creates a potential for understating saving relative to the perceptions of option holders. Yet, the NIPA measure of business profits usually fails to include stock options as a potential expenditure before expiration, and this also leads to the systematic inflation of the estimates of business saving, with compensating effects. ${ }^{15}$ In any event, the NIPA accounts show that total deferred compensations to workers (of which stock options are just one example) accounts for at most 0.3 percent of personal income, and therefore hardly explains the recent, major swings in the saving rate.

\section{The FoF Measure of the Personal Saving Rate}

Estimates of the assets and liabilities of the personal sector are available in the FoF accounts of the Federal Reserve BOG. These accounts also provide estimates of holding gains and losses for assets such as real estate and corporate equities, including assets held indirectly through mutual funds, pension funds, and life insurance con-

\footnotetext{
${ }^{15}$ After 2003, the BEA began to incorporate stock-option adjustments in corporate profit estimates for the periods that are treated using public financial reports. For example, the extrapolated corporate profits estimates for 2002 and 2003 have been revised andbecause the gains on exercised stock options declined from 2001 to 2002-the result has been an increase in the BEA's estimate of corporate profits for 2002.
}

tracts. The main competing method to estimate the saving rate can be derived from the FoF accounts published by the BOG. In essence, we use FoF data to estimate the left-hand side of (3). According to this FoF definition, the personal saving rate is simply given by the ratio between the change in the net wealth (net worth) of U.S. households and their disposable income. Ideally, the change in the value of the assets owned by U.S. households (net of their debt and obligations) should be measured applying current market prices. ${ }^{16}$ Figure 9 compares this alternative notion of the personal saving rate with the standard NIPA estimate. ${ }^{17}$

Although over the sample period 1954-2006 the two alternative measures provide rather different averages (11.3 percent for FoF statistics vs. 7.3 percent for NIPA), their time-series behavior is quite similar; by the end of 2005, the FoF personal saving rate also dips below 2 percent. ${ }^{18}$ Therefore it is clear that, although one feels compelled to provide an explanation for the recent dynamics of the saving rate when the FoF definition is also adopted, it does not appear that a difference between -1 percent (based on NIPA calculations) and +1.3 percent (based on FoF calculations) at the end of 2006 is economically meaningful: The saving rate of U.S. households appears to be currently low and to have quickly trended down after the mid-1990s.

What is the intuition for the finding that the FoF and NIPA estimates of the personal saving rate have been approximately identical (and small) after the turn of the century? In principle, this is a moot question because (3) tells us that the two measures should in principle give identical results. In practice, this is an interesting question because it should be obvious that, when calculating the quantities involved, both the BEA

\footnotetext{
${ }^{16}$ However, debt instruments, such as bonds, are carried at book value in the FoF accounts, so they are excluded from the calculations of holding gains and losses.

${ }^{17}$ To avoid devoting too much attention to high-frequency movements (induced by asset prices) that lack much economic meaning, we report eight-quarter moving averages of the seasonally adjusted FoF quarterly series.

${ }^{18}$ The correlation between the two series is in fact almost perfect, 0.96.
} 


\section{Figure 9}

\section{Personal Saving as a Percent of Disposable Personal Income (eight-quarter moving average, quarterly, SA)}

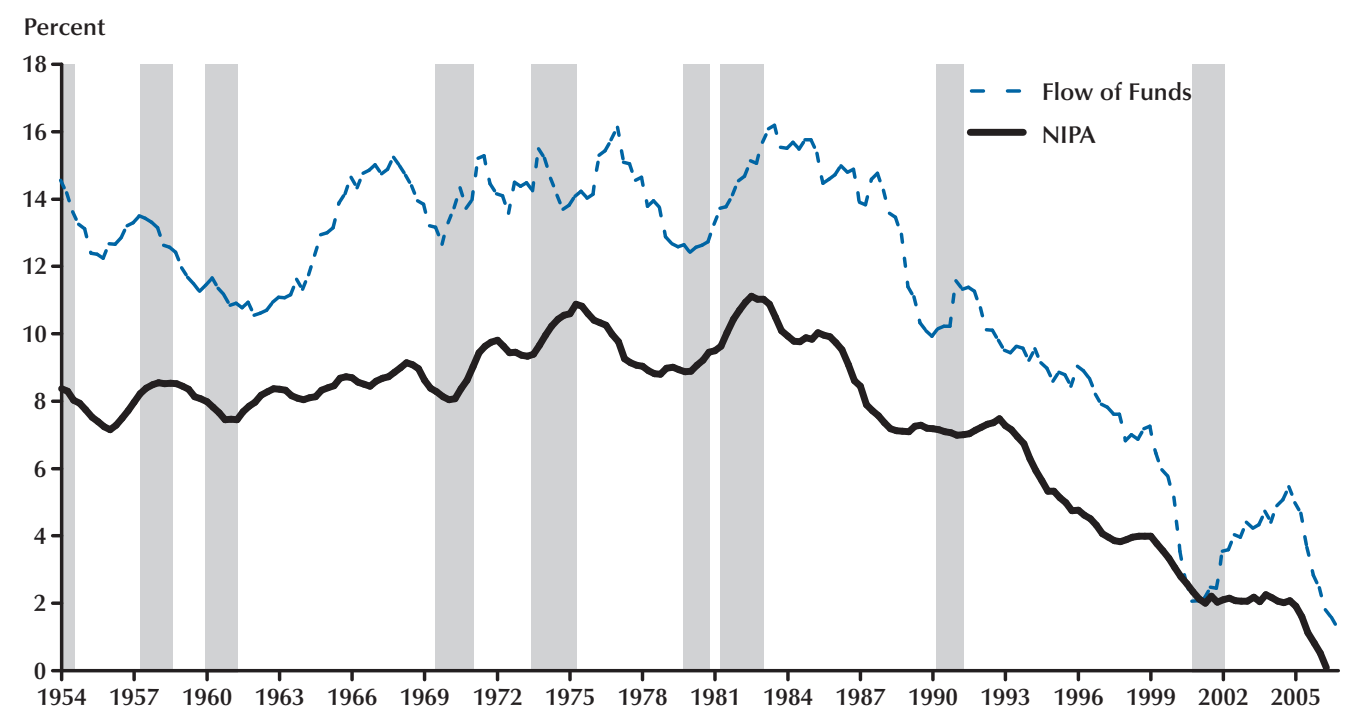

SOURCE: Bureau of Economic Analysis, Federal Reserve Board, Haver Analytics.

and the BOG need to make a number of working assumptions. It so happens, however, that many methodological practices are shared by the BEA and the BOG. For instance, both exclude capital gains from disposable income, both exclude pension benefits received from disposable income, and both deduct from personal disposable income the contributions paid into pension funds. ${ }^{19}$

\section{FURTHER DISCUSSION: SHOULD WE BE CONCERNED ABOUT THE DECLINE OF THE
PERSONAL SAVING RATE?}

We have shown that, even after taking into account a number of methodological and accounting issues, the recent decline in the U.S. personal saving rate is likely to correspond to a key economic phenomenon. Even if we may concede

\footnotetext{
${ }^{19}$ However the BOG considers the consumption of durable goods as
} part of gross private investment. that the current personal saving rate is probably not negative, it seems unquestionable that this rate has declined precipitously since the mid1990s. ${ }^{20}$ However, four arguments have appeared in the literature that may imply that there are (so far at least) no strong reasons to be concerned.

The first argument proposes that personal savings should be measured not from aggregate income and demand NIPA accounts (as routinely done by the BEA), but from data on the changes in the net worth (assets) of U.S. households.

\footnotetext{
${ }^{20}$ Note that BEA/NIPA estimates of the saving rate have been frequently revised up. In fact, the NIPA saving rate has approached zero at several points in recent history. In one of his speeches, former Philadelphia Fed President Santomero (2005) noted that a perception of a near-zero personal saving rate is far from new in economic history and seems to have occurred rather regularly if one looks at real-time data. For instance, 1980 now appears to have been characterized ex post by a relatively high personal saving rate; however, the reported, real-time 1980 NIPA personal saving rate was negative. See Nakamura and Stark (2005) for a discussion. Garner (2006, p. 16) anticipated an upward revision of the NIPA saving rate because the U.S. Census Bureau has revised downward its estimates of food services sales for recent years; his projected revision is on the order of 1.5 percent. Figure 1 reports the effects of the recent revision of July 31, 2007, using a dotted curve.
} 


\section{Figure 10}

\section{Measures of Wealth Accumulation as a Percent of Disposable Personal Income (eight-quarter moving average)}

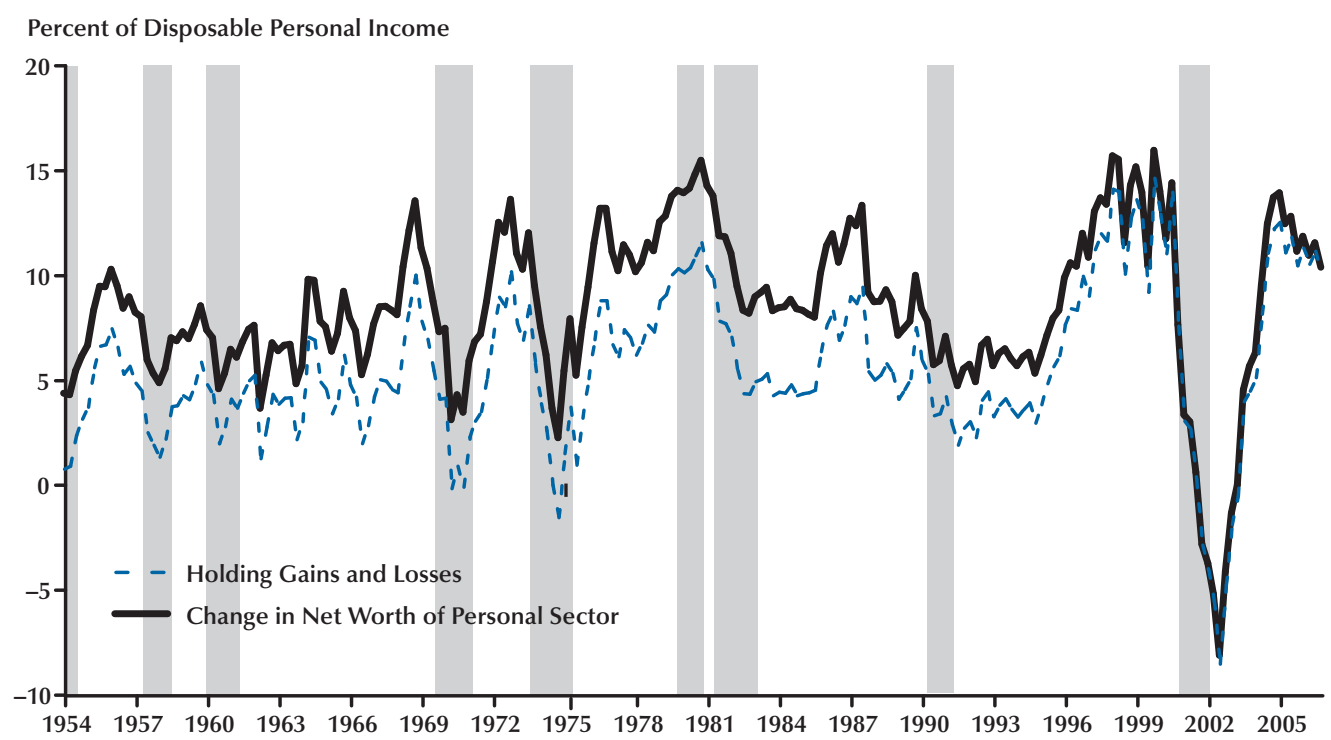

SOURCE: Federal Reserve Board.

Additionally, and differently from the current FoF practices of the BOG, this measure of savings should capture not only the acquisition cost of new assets, but also the sum of the acquisition costs and of the capital gains cumulated on the stock of existing wealth. For some types of applications (and policy analysis) this seems to be an appropriate notion. For instance, if policymakers are concerned that a re-entrenchment effect may be caused by retired households that need to cut their consumption because they are unable to support it, then there is little doubt that such households would/could finance their standards of living by selling assets in their net wealth, thus "cashing out" from their cumulated capital gains (see, e.g., Lusardi, 2000, p. 378). ${ }^{21}$ Many commentators have stressed that when capital gains are included in the picture, the U.S. personal saving

\footnotetext{
${ }^{21}$ There are other issues with the way FoF savings rates are computed. For instance, Reinsdorf (2004, p. 23) stresses that the BOG FoF accounts fail to give a complete picture of the changes in wealth because debt instruments (such as bonds) appear at book (not market) value.
}

rate either stops showing any trending tendency (see e.g., Poole, 2007) or if any trend appears, it is an upward one; that is, U.S. households appear to have saved more in the recent decade than previously. Figure 10 shows one such measure, the ratio between total net wealth accumulation and disposable income.

The dotted line shows why such a notion of the personal saving rate differs so much from the FoF estimate: In most of the years, the holding (as opposed to the realized) gains or losses represent most of the change in net wealth. This estimate of the personal saving rate is, in practice, below the FoF estimate (on average 5.6 percent vs. 11.3 percent) and similar to the standard NIPA average. However, it actually fails to trend down: For instance, between 1954 and 1994, the average saving rate would have been 5.1 percent versus 7.4 percent between 1995 and 2006.

However, to many commentators, it is not clear whether Figure 10 may actually represent an alternative definition of the personal saving rate, as opposed to a simple adjustment to the 


\section{Figure 11}

\section{Private Sector Financial Balances as a Percent of GNP (quarterly, SA)}

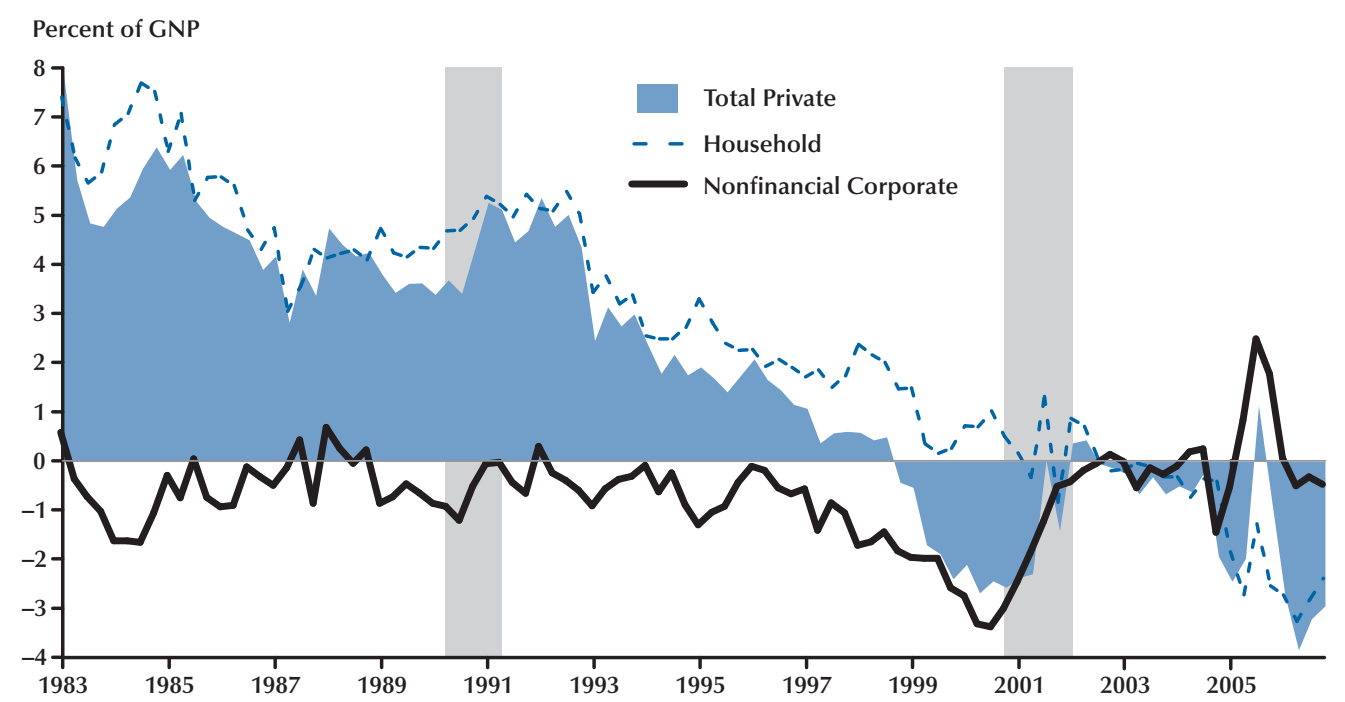

SOURCE: Bureau of Economic Analysis, Federal Reserve Board.

standard FoF definition. Clearly (and even after applying eight-quarter moving-average smoothing!) the wealth accumulation measure remains extremely volatile. This is natural because the numerator mostly reflects the dynamics of asset prices-mainly stocks, bonds, and real estatewhich easily manifest annualized volatilities exceeding 20 percent. Moreover, although 200506 turns out to have been a "thrifty" period (with average saving rates in excess of 12 percent), one wonders about the actual meaning of the -9 percent rate reached during 2002, in correspondence with the burst of the tech stock bubble of the late 1990s.

A second argument stresses that personal (household) savings cannot simply be assigned the role of the main, dominant component of private gross saving; (nonfinancial) businesses also can and do retain a portion of their profits to finance their investment activities. Earlier, we stressed that what really matters for healthy growth is that private saving exceeds private investment. This argument implies that the recent behavior of U.S. households may not be a reason for concern if, at the same time, U.S. nonfinancial firms have happened to increase their saving. This proposition-that net private saving would be roughly constant as a percentage of national income as a result of a strong negative correlation between personal and business saving-is famous in economics (it is often called Denison's law, from Denison, 1958). Unfortunately, it does not successfully withstand serious empirical scrutiny. ${ }^{22}$ Figure 11 shows the recent movement of household and business savings as a percentage of output. As previously stressed, gross private savings became negative for long periods at the end of the 1990s and between 2004 and 2005. This means that, although starting in the late 1990s there has been a tendency for nonfinancial corporations to retain a growing fraction of their earnings, such a trend does not fully compensate for the apparent

\footnotetext{
${ }^{22}$ Hendershott and Peek (1989) were the first to notice that such an inverse relationship between personal and business savings was largely an artifact of measurement problems. Parker (2000, p. 322) stresses that NIPA accounts do a very ambiguous job at separating household savings from business savings. This may justify why different researchers have reached a range of conclusions on the validity of Denison's law after the mid-1990s.
} 


\section{Figure 12}

\section{International Household Saving Ratios (quarterly)}

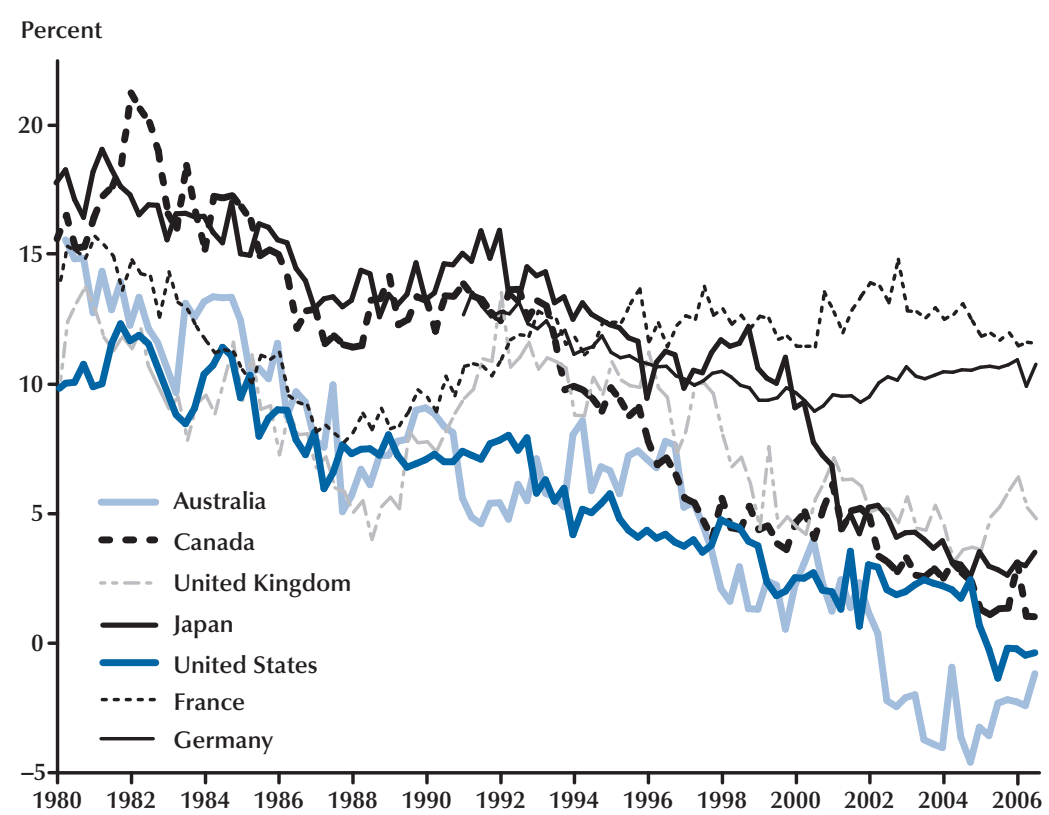

SOURCE: Organisation for Economic Co-operation and Development.

"consumption boom" that has at the same time characterized the behavior of U.S. households.

A third argument refers mainly to FoF estimates of the personal saving rate and leads to conclude that such a measure-certainly to be considered superior to NIPA measures, the argument goes-could be grossly underestimated at present. For instance, Hall (2000) has estimated that a large part of the increase in the net worth of U.S. households during the 1990s would have taken the form of what he calls "e-capital," a body of information-processing methods and organizational knowledge that has strongly increased the productivity of labor. Hall has argued that the accumulation of such e-capital by households would have created a new, intangible type of asset that should legitimately enter saving rate calculations. Obviously, a similar phenomenon would have involved U.S. firms that therefore would have a much higher net saving rate than recorded by the BEA. From this perspective, the recent decline in the U.S. personal saving rate would simply hide a shift from savings in the form of accumulation of traditional assets (stocks, bonds, houses) to what we could call "e-assets." In parallel, the net saving of U.S. businesses also might be substantially underestimated. Given the growing importance of information technology in a globalized world, the decline in the personal saving rate would actually reflect an encouraging development, likely to predict sustained productivity growth. Although some of these innovative notions of what constitutes an asset and what constitutes saving behavior are of key importance, at this point the estimates of the amount of annual investments as a percentage of GNP remain fairly uncertain and probably insufficient to explain the decline in the personal saving rate.

One final argument exploits the fact that the recent U.S. experience is not very different from the recent historical record of a number of developed countries. Figure 12 shows the personal 
saving rates for seven different countries. These comparisons should be accompanied by a word of caution because different countries are known to follow rather different national income accounting procedures. For instance, while the BEA has a rather complicated set of rules concerning imputations-that is, when a market value is placed on transactions that do not occur in the market economy or that are not observable in its recordsmany other countries (e.g., Germany) are known to mostly rely on market transactions for all that concerns their calculations of the saving rate. ${ }^{23}$

In spite of these qualifications, the recent downward trend in the personal saving rate clearly has failed to involve only the United States: Similar dynamics also characterize, for instance, Canada and Australia. ${ }^{24}$ In particular, the Australian saving rate has been negative since 2002. Furthermore, the Canadian personal saving rate appears now close to zero (it is 1.4 percent), which is remarkable because between 1970 and 1989 the Canadian rate had been 14 percent against 9 percent for the U.S. Thus, a gap of 5 percentage points appears to have almost disappeared in the past 17 years. In contrast, the evolution of both the U.K. and the German personal saving rates have been markedly different from that in the United States. The German rate does not appear to be drifting down over time and in the third quarter of 2005 was still exceeding 10 percent. Of course, differences in the accounting methodologies might explain a relevant portion of these differences. However, absent further evidence to explain the different behavior of U.S., Canadian, and Australian personal saving rates,

\footnotetext{
${ }^{23}$ Despite the general principle driving BEA practices that NIPA measures should reflect only market transactions in goods and services, imputations are included in personal income and in other NIPA aggregates, generally to keep the NIPA aggregates invariant to how certain activities are carried out. Specifically, six imputations are included in the estimates of personal income: imputed pay-in-kind, employer-paid health and life insurance premiums, the net rental value of owner-occupied farms and the value of food and fuel produced and consumed on farms, the net rental value of owner-occupied nonfarm housing, the net margins on owner-built housing, and the imputed interest paid by financial intermediaries except life insurance carriers. These imputations accounted for about 8 percent of personal income at the national level in 2001.

${ }^{24}$ The declining Japanese personal saving rate has received some distinct attention in the academic literature (see, e.g., Horioka and Watanabe, 1997).
}

the safest conclusion is that the recent level and evolution of the U.S. personal saving rate represents a puzzle in search of a convincing economic explanation, which is the subject of the following section.

\section{THE DECLINE OF THE PERSONAL SAVING RATE: IS IT A PUZZLE?}

In economics, a phenomenon is said to represent a puzzle when standard and generally accepted economic principles and theories fail to provide a quantitatively satisfactory explanation for a set of empirical regularities. In this case, the empirical "stylized fact" consists of the low and declining U.S. personal saving rate. As shown in Figure 1, such a trend manifested itself as early as in 1993. Therefore, economists and policymakers alike have had more than a decade to develop theories and models that might somehow explain the recent, anomalous behavior of the U.S. personal saving rate. Additionally, it seems now to be received wisdom that the drop in the U.S. saving rate is just a reflection of a contemporaneous "consumption boom" that has swept through the United States since the mid1990s (see Figure 13). At least six different theories/explanations for the recent dynamics of the personal U.S. saving rate have been put forth. We review them here. ${ }^{25}$

\section{Wealth Effects}

This theory is fairly simple and can be traced back to early theories that stressed that a household's net worth ought to influence its consumption/saving patterns: The occurrence of price run-ups in equity (during the late 1990s) and real estate (especially after 2001) markets have created bubble-like conditions in which high and growing capital gains (both realized and unrealized) together increase the current outlays by U.S. households. Lusardi, Skinner, and Venti (2001) conclude that on the basis of the bulk of

\footnotetext{
${ }^{25}$ Our review of the literature is necessarily incomplete. The milestones of the debate on the declining U.S. saving rate seem to be Bosworth, Burtless, and Sabelhaus (1991), Browning and Lusardi (1996), Gale and Sabelhaus (1999), and Parker (2000).
} 


\section{Figure 13}

\section{Rate of Personal Consumption Expenditure to Disposable Personal Income (quarterly, SAAR)}

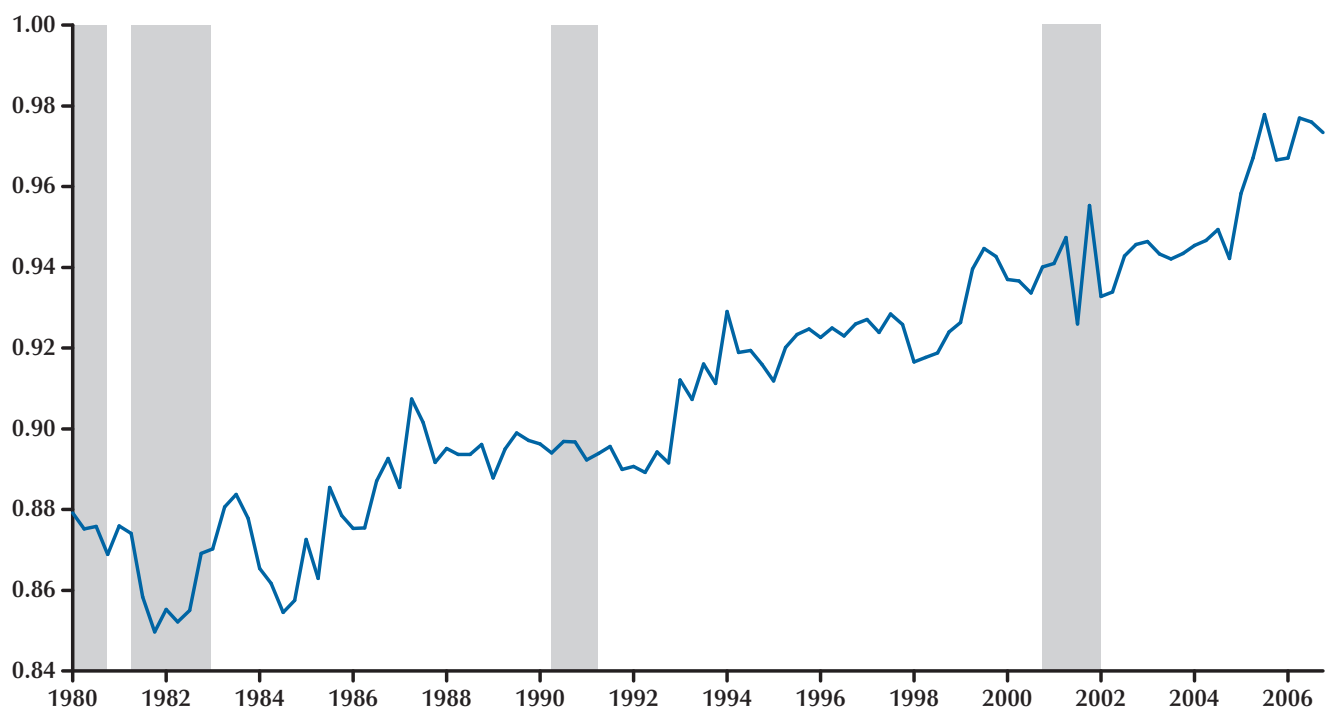

SOURCE: Bureau of Economic Analysis.

the econometric evidence, the appreciating stock market wealth since 1988 may have reduced the personal saving rate between 3 and 5 percentage points. Dynan and Maki (2001) and Juster et al. (2006) have reported estimates from micro-level data that are consistent with this conclusion. Although this explanation is intuitively (and quantitatively) appealing, a number of researchers have expressed doubts. For instance, Parker (2000, p. 330) objects that the timing of recent bubbles seems to follow the decline of the U.S. saving rate. The rate kept declining even during 2001 and 2002, when the stock market bubble burst and billion of dollars of unrealized (paper) capital gains were lost (see, e.g., Figure 4). Because the recent U.S. saving rate data imply an elasticity of about one-sixth, this means that the stock market bull periods of the late 1990s should have generated (but did not) a large response of consumption, whereas the strongest dip in the saving rate seems to have occurred after 2002. Lettau and Ludvigson (2004) find that a vast majority of variation in asset wealth is purely transitory and as such tends to have no impact whatsoever on consumer spending, implying that wealth effects represent a plausible explanation only if we believe that most stock and housing market booms in the past two decades were largely due to permanent, structural shifts in the way assets are evaluated. Additionally, Poterba and Samwick (1995) and Ludivgson and Steindel (1999) have shown that the structure of lagged effects connecting consumption to wealth changes are rather complicated and generally support only short-lived and weak effects. Finally, Lusardi, Skinner, and Venti (2001) correctly stress that although the decline in personal saving seems to have involved most cohorts/types of households, only roughly half of the U.S. population holds stocks. The fraction holding housing properties is only slightly higher.

\section{Permanent Income Hypothesis (the "New Economy" Effect)}

According to this theory, recent technological advances and enormous increases in labor productivity would have led U.S. households to apply vigorous upward revisions to their permanent-income estimates (see, e.g., Greenwood and 
Jovanovic, 1999). In this case, the unobservable effective saving rate perceived by households is

$$
\hat{s}_{t+1}=\frac{Y_{t+1}^{p}-C_{t+1}}{Y_{t+1}^{p}},
$$

where $Y_{t+1}^{p}$ is some present discounted value of the stream of future incomes (after taxes),

$$
Y_{t+1}^{p} \equiv Y_{t+1}+\sum_{j=1}^{\infty} \beta^{j} Y_{t+1+j}
$$

In words, The permanent income can be described as a smoothly growing measure whose value corresponds to the present value of all real resources available to a consumer. When $Y_{t+1}^{p}>Y_{t+1}$, it is possible for agents to perceive (and act upon)

$$
\hat{s}_{t+1}>s_{t+1}^{N I P A} \equiv\left(Y_{t+1}-C_{t+1}\right) / Y_{t+1} .
$$

In practice, the wealth-effects explanation stresses the effects of the increases in the net worth of households, whereas the permanentincome theory relies more on revisions of the expectations of future incomes. Although many researchers have noticed that this latter explanation is consistent with the fact that the high rate of growth of productivity has survived the recession of 2002 (see, e.g., Parker, 2000, p. 319), most recent research has concluded that productivity effects may explain, at most, 20 percent of the recent changes in the saving rate.

\section{Financial Innovation}

This model stresses that improvements in the credit markets have made it possible to transform unrealized capital gains and future incomes into current purchasing power (see, e.g., Carroll, 1997). Examples are "exotic" (interest-only) mortgages and subprime rate loans and revolving debt with flexible payment features (e.g., credit cards and overdraft plans on checking accounts). In this case, households do not need to perceive a higher stream of current incomes to increase consumption; a given level of permanent income becomes easy to convert into current consumption as the financial innovation process progresses. According to this model, U.S. households would have plunged into increasing debt. For instance,
Kennickell and Starr-McCluer (2000) show that the median amount of outstanding household debt has almost doubled between the end of the 1980s and the turn of the new millennium. Empirically, this explanation has been remarkably successful. For instance, Parker (2000) concludes that the increase in the debt/GDP ratio can explain a remarkable one-third of the observed decline in U.S. personal saving. Gokhale, Kotlikoff, and Sabelhaus (1996) have noticed also that the increasing annuitization of retirement income in the United States may exert some downward pressure on the NIPA saving rate. Yet, a few commentators have expressed reservations about the effects of financial innovations. For instance, Lusardi et al. (2001) remark that the FoF accounts show that the drop in the saving rate has much more to do with households' failure to purchase sufficient financial assets than with their propensity to increase their financial liabilities.

\section{Social Security Programs and Macroeconomic Stability}

This explanation relies once more on the mechanism of expectation formation. It stresses that U.S. households, faced with the evidence that Social Security, Medicare, and other government transfer programs work, have increased their consumption levels, feeling that their own personal saving might not be needed as much as they age or experience other debilitating events. For instance, Lusardi et al. (2001) update original calculations in Gokhale, Kotlikoff, and Sabelhaus (1996) and observe that the entire growth in the ratio of consumption to GDP between 1988 and 2000 (roughly 2 percentage points) can be explained by increases in medical care expenditures. This may reveal that consumption has increased simply because social programs are in fact assumed to be paying for the additional expenditure. Huggett and Ventura (2000) and Gustman and Steinmeier (1999) have argued that especially households in the lowest wealth-distribution brackets, which also tend to be relatively young, may rationally expect generous relative (post"Baby Boom") retirement benefits, either from Social Security or from other pension plans. 
Another take on these expectations is that, as households and firms perceive declining macroeconomic risks (e.g., of inflation) as a result of sound economic policies, they might progressively reduce their "precautionary saving" that is supposed to work as a buffer during "bad times." In this respect (and paradoxically), a successful Fed policy might have contributed to long-run instability through a progressive reduction of private saving rates. ${ }^{26}$

\section{Demographics}

According to the life-cycle hypothesis of consumption, individuals save when young and dissave when old. If the American population is aging, a decline in the personal saving rate is to be expected. Although there is now some empirical evidence that this explanation might provide a good fit for the Japanese saving decline (see, e.g., Horioka and Watanabe, 1997, and more recently Chen, Imrohoroglu, and Imrohoroglu, 2007), the evidence for the United States is rather weak (see, e.g., Parker, 2000). Browning and Lusardi (1996) offer a rather compelling explanation for why aging cannot work as a main explanation: Aging happens too slowly to generate sufficient variation to explain the U.S. case. Moreover, Lusardi, Skinner, and Venti (2001) do find that the demographic structure of the U.S. population is shifting and that a significant group of households have saving rates too low to be explained by conventional life-cycle models. Notice, however, that this is the opposite of a sensible explanation of the puzzle, because economists so far have not been able to explain why exactly such a cluster of households has difficulty recognizing the need to save and calculating the amount of savings they need. ${ }^{27}$

\footnotetext{
${ }^{26}$ This explanation can also be read as suggesting that U.S. households are applying a higher level of (effective) subjective discount factors when deciding optimal consumption patterns. Parker (2000, p. 331) observes that this is consistent with the recent evidence of high real interest rates in the United States.

${ }^{27}$ A number of behavioral models have been proposed to interpret this behavior. For instance, Laibson, Repetto, and Tobacman (1998) suggest that people may display hyperbolic rather than exponential discount functions, which implies that short-run discount rates are higher than long-term rates, so that decisionmaking appears to be time inconsistent.
}

\section{Ricardian Equivalence}

Consider a world in which Ricardian equivalence applies: Unless taxes are distortionary, higher taxes should induce households to save less, given a steady level of public expenditures and hence higher public saving. As we noted earlier, a net increase in public sector savings has taken place only between 1993 and 1999, while private saving has kept sliding. Hall (1999) argues that most of the changes in the composition of total national saving between the 1980s and 1998 may be explained by an application of Ricardian neutrality, which is consistent with the empirical findings in Tanzi and Zee (1998) for saving rates and tax data for a panel of countries in the Organisation for Economic Co-operation and Development. However, in quantitative terms, Parker (2000) also rejects that households might simply be acting on the basis of expected, future reductions of budget deficits, as the reductions to be anticipated would have to be implausibly high and historically unprecedented.

\section{Trends in the Way Companies Compensate Shareholders}

Financial economists have for decades alerted the economics profession that-for a variety of reasons, related to both institutions (corporate governance mechanisms) and taxes-U.S. corporations have become less and less inclined to pay cash flows to stockholders in the form of dividends. The standard motto is that "dividends are disappearing." From this perspective, the preferred way of compensating stockholders would increasingly be stock repurchases (both directly and as a part of tender offers) and swaps of stocks with bonds and other liquid securities. With a complete shift away from dividends, the amount of stock repurchases by all U.S. non-financial corporations has increased from $\$ 42$ billion in 2003 to $\$ 602$ in 2006, an increase by a factor of 14 ! Currently, cash dividend payments are included in the NIPA definition of disposable income, yet share repurchases are not. Measurement of the saving rate is further complicated because possible taxes paid on the repurchase gains are taken into account, reducing personal disposable 
income. Simple math shows that, with the saving rate defined as $s_{t+1}=\left(Y_{t+1}-C_{t+1}\right) / Y_{t+1}$, if $Y_{t+1}$ gets underestimated, then $s_{t+1}$ will be unduly underestimated. Recent estimates by Steindel (2007) show that almost one-third of the recent saving rate decline may be explained away by this structural change in the way stockholders are compensated. However, the trend is rather recent and, although the saving rate has been falling at least since the early 1990s, these developments in the ratio between cash dividends and stock repurchases have assumed large proportions only in recent years. Additionally, it may be argued that only a portion of a share repurchase actually represents a permanent income component.

\section{CONCLUSIONS}

Many economists have stressed that a number of flaws characterize the most widely known estimates of the U.S. personal saving rate. However, none of the problems of the measures currently used (NIPA and FoF rates) seems to fully account for the steep decline and the negative levels reached by the U.S. saving rate after the mid1990s. Moreover, even when the recent dynamics of households' net wealth, the saving of nonfinancial firms, and the declining saving rates in a number of developed countries are taken into account, there is reason to be concerned about the low level reached by the U.S. personal saving rate after the mid-1990s. These concerns are spurred by the possibility that U.S. households may soon re-entrench and reduce their consumption expenditures. There are also long-term worries that the United States might either be prevented from financing all of the available, positive net present value investment opportunities or forced to accept a high and increasing dependence on foreign lending. Although we have reviewed a number of concurring explanations that have been proposed for the declining propensity of U.S. households to save, it seems that (sometimes on logical grounds, in other occasions on an empirical level) such theories remain insufficient to explain the entire magnitude of the recent transformation of the United States into a nation of spendthrifts. In this sense, the U.S. personal saving rate remains a puzzle.

\section{REFERENCES}

Bosworth, Barry; Burtless, Gary and Sabelhaus, John. "The Decline in Saving: Evidence from Household Surveys." Brooking Papers on Economic Activity, 1991, No. 1, pp. 183-241.

Browning, Martin and Lusardi, Annamaria. "Household Saving: Micro Theories and Micro Facts." Journal of Economic Literature, December 1996, 34, pp. 1797-855.

Carroll, Christopher D. "Buffer-Stock Saving and the Life Cycle/Permanent Income Hypothesis." The Quarterly Journal of Economics, February 1997, 112(1), pp. 1-55.

Chen, Kaiji; Imrohoroglu, Ayse and Imrohoroglu, Selahattin. "The Japanese Saving Rate between 1960 and 2000: Productivity, Policy Changes, and Demographics." Economic Theory, July 2007, 32(1), pp. 87-104.

Denison, Edward F. "A Note on Private Saving." Review of Economics and Statistics, August 1958, 40(3), pp. 261-67.

Dynan, Karen E. and Maki, Dean M. "Does Stock Market Wealth Matter for Consumption?” Finance and Economics Discussion Series No. 2001-23, Board of Governors of the Federal Reserve System, 2001.

Fleming, Wendell H. and Stein, Jerome L. "Stochastic Optimal Control, International Finance and Debt." Journal of Banking and Finance, May 2004, 28(5), pp. 979-96.

Gale, William, G. and Sabelhaus, John. "Perspectives on the Household Saving Rate." Brooking Papers on Economic Activity, 1999, No. 1, pp. 181-222.

Garner, Alan C. "Should the Decline in the Personal Saving Rate Be a Cause for Concern?” Federal Reserve Bank of Kansas City Economic Review, Second Quarter 2006, pp. 5-28. 
Gokhale, Jagadeesh; Kotlikoff, Laurence, J. and Sabelhaus, John. "Understanding the Postwar Decline in U.S. Saving: A Cohort Analysis." Brooking Papers on Economic Activity, 1996, No. 1, pp. 315-407.

Guimaraes, Bernardo. "Optimal External Debt and Default.” Discussion Paper No. 6035, Center for Economic Policy Research, January 2007.

Gustman, Alan L. and Steinmeier, Thomas L. "Effects of Pensions on Savings: Analysis with Data from the Health and Retirement Study." Carnegie-Rochester Conference Series on Public Policy, June 1999, 50, pp. 271-324.

Greenwood, Jeremy and Jovanovic, Boyan. "The Information-Technology Revolution and the Stock Market." American Economic Review, May 1999, 89(2), pp. 116-22.

Hakkio, Craig S. and Wiseman, Elisha J. "Social Security and Medicare: The Impending Fiscal Challenge." Federal Reserve Bank of Kansas City Economic Review, First Quarter 2006, pp. 7-41.

Hall, Robert E. Comment on "Perspectives on the Household Saving Rate" by Gale and Sabelhaus, Brooking Papers on Economic Activity, 1999, No. 1, pp. 215-20.

Hall, Robert E. "E-Capital: The Link Between the Stock Market and the Labor Market in the 1990s." Brooking Papers on Economic Activity, 2000, No. 2, pp. 73-118.

Hendershott, Patric H. and Peek, Joe. "Aggregate U.S. Private Saving: Conceptual Measures and Empirical Tests," in Robert E. Lipsey and Helen Stone Tice, eds., The Measurement of Saving, Investment and Wealth. Chicago: University of Chicago Press, 1989, pp. 185-226.

Horioka, Charles Yuji and Watanabe, Wakō. "Why Do People Save? A Micro-Analysis of Motives for Household Saving in Japan." The Economic Journal, May 1997, 107(442), pp. 537-52.

Huggett, Mark and Ventura, Gustavo. "Understanding Why High Income Households Save More than
Low Income Households." Journal of Monetary Economics, April 2000, 45(2), pp. 361-97.

Juster, Thomas F.; Lupton, Joseph P., Smith, James P. and Stafford, Frank. "The Decline in Household Saving and the Wealth Effect." The Review of Economics and Statistics, November 2006, 88(1), pp. 20-27.

Kennickell, Ann and Starr-McCluer, Martha. "Recent Changes in U.S. Family Finances: Results from the 1998 Survey of Consumer Finances.” Federal Reserve Bulletin, January 2000, pp. 1-29.

Laibson, David; Repetto, Andrea and Tobacman, Jeremy. "Self-Control and Saving for Retirement." Brooking Papers on Economic Activity, 1998, No. 1, pp. 91-172.

Lettau, Martin and Ludvigson, Sydney C. "Understanding Trend and Cycle in Asset Values: Reevaluating the Wealth Effect on Consumption." American Economic Review, March 2004, 94(1), pp. 276-99.

Ludvigson, Sydney and Steindel, Charles. "How Important Is the Stock Market Effect on Consumption?” Federal Reserve Bank of New York Economic Policy Review, July 1999, 5(2), pp. 29-51.

Lusardi, Annamaria. "Spendthrift in America? On Two Decades of Decline in the U.S. Saving Rate: Comment," in Ben S. Bernanke and Julio J. Rotemberg, eds., NBER Macroeconomics Annual 1999. Cambridge, MA: MIT Press, 2000, pp. 374-86.

Lusardi, Annamaria; Skinner, Jonathan and Venti, Steven. "Saving Puzzles and Saving Policies in the United States." Oxford Review of Economic Policy, Spring 2001, 17(1), pp. 95-115.

Nakamura, Leonard I. and Stark, Tom. "Benchmark Revisions and the U.S. Personal Saving Rate." Working Paper No. 05-6, Federal Reserve Bank of Philadelphia, April 2005.

Parker, Jonathan A. "Spendthrift in America? On Two Decades of Decline in the U.S. Saving Rate," in Ben S. Bernanke and Julio J. Rotemberg, eds., 
NBER Macroeconomics Annual 1999. Cambridge, MA: MIT Press, 2000, pp. 317-70.

Peach, Richard W. and Steindel, Charles. "A Nation of Spendthrifts? An Analysis of Trends in Personal and Gross Saving." Federal Reserve Bank of New York Current Issues in Economics and Finance, September 2000, 6(10), pp. 1-6.

Perozek, Maria G. and Reinsdorf, Marshall B. "Alternative Measures of Personal Saving." Survey of Current Business, April 2002, 82(4), pp. 13-24.

Poole, William. "How Dangerous Is the U.S. Current Account Deficit?” Economic Policy Lecture Series, Lindenwood University, St. Charles, MO, November 9, 2005; http://stlouisfed.org/news/ speeches/2005/11_09_05.htm.

Poole, William. "U.S. Saving." Presented at the CFA Society of Nebraska, Omaha, NE, February 15, 2007; http://stlouisfed.org/news/speeches/ 2007/02_15_07.html.

Poterba, James M. "Stock Market Wealth and Consumption." Journal of Economic Perspectives, Spring 2000, 14(2), pp. 99-118.

Poterba, James M. and Samwick, Andrew A. "Stock Ownership Patterns, Stock Market Fluctuations, and Consumption.” Brooking Papers on Economic Activity, 1995, No. 2, pp. 295-357.
Reinsdorf, Marshall B. "Alternative Measures of Personal Saving." Survey of Current Business, September 2004, 84(9), pp. 17-26.

Reinsdorf, Marshall B. "Alternative Measures of Personal Saving." Survey of Current Business, February 2007, 87(2), pp. 7-13.

Santomero, Anthony M. "Making Monetary Policy: What Do We Know and When Do We Know It?" Presented at the National Economists Club, April 7, 2005; www.philadelphiafed.org/publicaffairs/ speeches/santomero/2005/04-07-05_natleconomists-club.cfm.

Steindel, Charles. "How Worrisome Is a Negative Saving Rate?" Federal Reserve Bank of New York Current Issues in Economics and Finance, May 2007, 13(4), pp. 1-7.

Tanzi, Vito and Zee, Howell H. "Taxation and the Household Saving Rate: Evidence from OECD Countries.” IMF Working Paper No. 98/36, International Monetary Fund, March 1998. 